\title{
Karierno svetovanje za prehode v kontekstu konstruktivizma
}

\author{
Janez Drobnič \\ Univerza na Primorskem \\ janez.drobnic@pef.upr.si \\ Katarina Česnik \\ Univerza na Primorskem \\ katarina.cesnik@pef.upr.si
}

Sodobne metode konstruktivističnega svetovanja postajajo vse bolj razširjene v sedanjem času dinamičnih sprememb poudarjanja avtonomnosti in lastne odgovornosti posameznika za svojo kariero. S prispevkom zato predstavljamo pristope $v$ okviru kontekstualizma/konstruktivizma in novosti, ki jih prinašajo v novodobno karierno svetovanje. Kot sodobno metodo konstruktivističnega svetovanja prepoznavamo narativno metodo. Ta se je relativno nedavno pojavila v poklicni psihologiji in praksi kariernega svetovanja. Pripoved v kariernem svetovanju služi konstrukciji pomena o sebi in lastni karieri skozi zgodbe in jezik, v novodobno karierno svetovanje pa prinaša pomen razumevanja posameznikovih čustev, (meta)kognicije, učenja, ciljne naravnanosti, prilagodljivosti, naučenega optimizma in osebne odgovornosti za vodenje lastne kariere. Zgodbe namreč služijo kot most pri odločanju za morebitne prehode v kariernem razvoju.

Ključne besede: konstruktivizem, kontekstualizem, karierno svetovanje, prehodi, vodenje kariere

\section{Uvod}

Odločitve glede nadaljnjega izobraževanja ali poklicne kariere za mlade nikoli niso bile preproste (Niklanović 1997), še zlasti pa to velja za posameznike s posebnimi potrebami in druge ranljive skupine na trgu dela (Drobnič 2018; Kravos 2019). V sedanjem dinamičnem času, ki ga zaznamuje kompleksnost v povezovanju različnih družbenih sistemov (Patton in McMahon 2014), se vse bolj pojavljata negotovost in stiska pri odločanju o življenjskih in ne zgolj poklicno-kariernih odločitvah. Bright (2013) to domišljeno opiše z izrekom, da je edina gotovost $v$ sedanjem času ta, da je vse negotovo. Ni namreč več mogoče zanesljivo predvideti, kaj se bo z nami zgodilo v prihodnosti (Ažman idr. 2014). Zato se nujno postavi vprašanje primernega kariernega svetovanja, ki bi olajšalo stiske in negotovosti posameznika pri novodobnem kariernem vodenju ter mu omogočalo lažje odločanje ob kariernih prehodih. 
Po Youngu idr. (2011) so prav prehodi tisti, ki posameznike najpogosteje usmerjajo k iskanju kariernega svetovanja, in ni nujno, da se prehodi nanašajo zgolj na poklicno kariero. Za najbolj tvegan prehod namreč ocenjujejo prav prehod iz mladostništva v odraslost (Young idr. 2011), po Savickasu (Lablarios 2013) pa so prav ti posamezniki tisti, ki jih lahko razumemo kot ranljivo populacijo, saj so v današnjem, kompleksnem svetu prikrajšani za odločanje - odločajo se z odlašanjem. Zato ni presenetljivo, da se literatura v okviru kariere nanaša predvsem na pristope $v$ kariernem svetovanju, ki se usmerjajo $v$ mladostnike na prehodu v odraslost (Young idr. 2011), pri tem pa ne moremo zanikati, da se s pomembnimi prehodi soočajo tudi odrasli in potrebujejo pomoč pri sprejemanju novih življenjskih vlog in odločitev, ki bodo v skladu s temi vlogami. Vendarle pa je po Youngu idr. (2011) v obdobju prehoda v odraslost verjetneje, da posamezniki takrat rekonstruirajo svoje cilje in nadaljnjo pot; za to pa potrebujejo nove strategije, vedenja in vire, ki so v skladu s sodobnimi družbenimi spremembami in trendi.

\section{Problem, namen in cilji}

Od začetka zgodnjih devetdesetih let 20. stoletja je poklicno-karierno svetovanje prevzemalo tradicijo pozitivističnega pogleda na svet (zrcali se v delih Parsonsa, Hollanda, Roejeve, Ginzberga idr.), ki temelji na testiranju oz. ocenjevanju posameznikovih lastnosti, pri čemer svetovalec pri testiranju in svetovanju prevzema vlogo strokovnjaka, stranka oz. svetovanec pa pasivnega odzivnika (Drobnič 2020). Collinova (1997) ter Collinova in Young (1986) so ugotovili, da so bile teorije kariere do zdaj v veliki meri razvite v okviru organicističnih in mehaničnih perspektiv ${ }^{1}$ ter kot take ne služijo več novodobnem konstruiranju kariere. Razvijati je treba nove pristope. Ena izmed novih paradigem, ki uokvirja novodobne pristope, je kontekstualna, ki posameznikov razvoj pojmuje kot nenehni proces interakcije med posameznikom in njegovim okoljem (Patton in McMahon 2014), na katerega pa vplivajo naključja. Zato nas Collinova (1997) v okviru kontekstualizma spomni, da moramo danes ubrati drugačen pristop k svetovalnemu procesu. Svetovanec v takšnem svetovalnem procesu ni več pasiven, temveč je v njem aktiven, s svetovalcem

\footnotetext{
${ }^{1}$ Po Pepperju (1942) in Collinovi (1997) poznamo štiri glavne poglede na svet - organicizem, formizem, mehanizem in kontekstualizem. Mehaničistična perspektiva na svet gleda tako, kot da deluje vse na podoben način, kot stroj, in nakazuje, da razmišljamo linearno, od splošnega do posebnega, in da pojave pojasnjujemo z vzročno-posledičnimi izrazi. Organicistični pogled pa človekov razvoj vidi kot urejen, zrel proces. Je osnova modelov v razvojni psihologiji (Collin in Young 1986), ki jih vidimo zlasti pri teoretikih kariernega razvoja, npr. v delih Superja (1990), Ginzberga (1984) in Gottfredsonove (2002) na področju poklicne psihologije.
} 
je v interakciji in skupaj v tem procesu tvorita pomen. Vendar Collinova (1997) pravi, da kontekstualizem na področju kariere še ni široko prepoznan, čeprav je pomemben, saj zajema fleksibilnost in razdrobljenost današnje kariere. Vse bolj je torej pomembno, da se usmerjamo v proces gradnje in kontekst kariere, saj le tako lahko razumemo njeno odprtost, fleksibilnost, brezmejnost ... Različne teorije kariere in pristope $v$ kariernem svetovanju pa moramo razumeti zgolj kot različne perspektive, lokalne in nikakor ne univerzalne oz. globalne.

Konstruktivistični pogled na svet vedno bolj vpliva na pristope $\mathrm{h}$ kariernemu svetovanju. Dandanes se ga namreč razume kot vsesplošno vrednoto sodobnega časa (Knol 2011), ki ga prioritizira zahodna družba (Fox 2001; Richardson 2003), ta ideja pa se širi tudi v druge kulture s pomočjo vesternizacije (Klemenčič 2012). Če pozitivisti poudarjajo racionalnost, ki temelji na objektivnosti (Savickas 2012) in dejstvih, konstruktivistični pristop temu pogledu ne nasprotuje. Po Pattonovi in McMahonovi (2018) je izpeljan iz kontekstualističnega pogleda na svet, saj trdi, da je »resničnost « zgrajena skozi posameznikovo lastno razmišljanje in obdelavo; te konstrukcije temeljijo na posameznih spoznanjih v interakciji s perspektivami, oblikovanimi iz interakcij med okoljem in osebami.

Karierne teorije pod vplivom konstruktivizma tako vse bolj prepoznavajo povezave med posamezniki in njihovim okoljem; vse bolj se zavedajo, da imajo posamezniki aktivno vlogo pri razumevanju, iskanju pomena v svetu, $\checkmark$ katerem živijo - dogajata se konstrukcija in rekonstrukcija pomena (Savickas 1993). Zatorej kontekstualizma ne moremo ločevati od konstruktivizma prvi je namreč integriran v drugega.

Naš raziskovalni cilj je preučiti novosti, ki jih prinaša karierno svetovanje v okviru kontekstualizma/konstruktivizma. Izhajamo iz ključnih težav, ki se pojavljajo v sodobnem svetu v zvezi s potekom kariere. Modeli, ki jih danes še uporabljamo in temeljijo na tradicionalnem, pozitivističnem pogledu na svet, so namreč zastareli, ker nimajo zadostne uporabnosti za realne, dinamične razmere na trgu dela, zato so potrebne alternative (Patton in McMahon 2006; Reid 2017). Teh pa nastaja vse več, zato terjajo analizo, ki bo koristna za strokovno prakso kariernega svetovanja, ker tem alternativnim modelom po McMahonovi in Watsonu (2015) manjkajo ključna orodja za izvajanje prakse kariernega svetovanja. Nujno je, da poudarjajo kvalitativne metode (npr. pogovor s stranko v svetovalnem procesu, opazovanje, testi brez številskega ocenjevanja itn.) namesto kvantitativnih (ocenjevanje, testiranje, ki temelji na številski oceni posameznikovih lastnosti), ki so prevladovale v prejšnjih, bolj pozitivističnih pristopih. 
Zato predstavljamo nekatere pristope, ki jih pri novodobnem kontekstualistično-konstruktivističnem kariernem svetovanju vrednotimo kot pomembne in ki sicer v pretežni meri izhajajo iz socialno-kognitivne psihologije in socialnega konstruktivizma. $V$ ta namen si postavljamo dve raziskovalni vprašanji. Najprej nas zanima, kateri pristopi v kariernem svetovanju se vrednotijo kot pomembni, uporabni v današnjem času ter katere novosti, ki izhajajo iz kontekstualizma/konstruktivizma, se pojavljajo v sodobnih praksah kariernega svetovanja.

\section{Pristopi kariernega svetovanja v okviru konstruktivizma}

Menimo, da je najbolje, če začnemo s teorijo o karieri v okviru kaosa, saj nas spomni, da moramo novodobno kariero najprej razumeti skozi družbene spremembe $v$ okviru globalizacije. Teorija današnjo družbo vidi kot kaotično in se zaveda, tako kot pravi Collinova (1997), da nanjo vplivajo družbene, tehnološke, kulturne in ekonomske spremembe.

\section{Svetovanje v pogojih družbenega kaosa}

Teorija kaosa je danes po Biswasovi, Hasanu in Bali (2018) ključna teorija, ker preučuje kompleksen, nelinearen, dinamičen sistem, ki se zrcali tudi v svetu dela (Schlesinger in Daley 2016). Kaotični sistemi so nestabilni, občutljivi predvsem na zunanje vplive; gibanje sistema je nelinearno, naključno, zato ga je težko napovedati (Biswas, Hasan in Bala 2018). Teorija kaosa v karieri po Pryorju, Amundsonu in Brightu (2008) razlaga, da je svet dandanes dinamičen in kompleksen sistem - kot sistem kaosa. Prav tako predpostavlja, da na posameznikovo dojemanje realnosti vplivajo predvsem njegove izkušnje (Pryor, Amundson in Bright 2008), torej je njegovo dojemanje realnosti predvsem subjektivno. Trdimo, da se teorija zelo povezuje z razumevanjem sveta, značilnim za čas neoliberalizma (Klemenčič 2012), ki poudarja pomen individuuma in njegove osebne odgovornosti za lastno kariero (Pryor, Amundson in Bright 2008). Teorija kaosa pa tako kot družbo tudi posameznike razume kot kompleksne, dinamične sisteme (Pryor, Amundson in Bright 2008), zatorej bi lahko dejali, da se pravzaprav ukvarja s spektrom različnih, dinamičnih vplivov na karierno odločanje posameznikov. Po Pryorju, Amundsonu in Brightu (2008) to dinamičnost narekujejo prav naključja, ki pa jih mora posameznik vnesti v svoj karierni načrt.

Pristop v kariernem svetovanju v okviru teorije kaosa svetuje uporabo strategij, ki integrirajo iskanje stabilnosti in rezilientnost, zaradi mnogih sprememb, tveganj in naključij. Po Pryorju Amundsonu in Brightu (2008) si mora namreč posameznik danes pri kariernem odločanju postavljati tiste odloči- 
tve, ki so najbolj logične za realizacijo. Pri tem pa si lahko pomaga na več različnih načinov, npr. $z$ uporabo različnih (tudi standardiziranih) testov, informiranjem, s preučevanjem ekonomskih in družbenih trendov, $z$ iskanjem čim več priložnosti oz. izkušenj, s katerimi lahko pride do znanja ... Pri tem mora biti previden, skrbno mora pretehtati vse informacije, da se lahko razumno odloči (Pryor, Amundson in Bright 2008) - tu pa se zopet pojavlja pomen osebne odgovornosti za zrelo, dobro karierno odločitev. Pryor, Amundson in Bright (2008) namreč trdijo, da morajo biti posamezniki pri odločanju odgovorni in pozitivno naravnani (rezilientni) - torej naj se ne prepustijo strahu, ki jim onemogoča uresničevanje ciljev; naj iščejo vse možne poti do znanja, naj tvegajo, se učijo iz neuspehov, celo pozivajo jih, naj sledijo svoji intuiciji in strastem. Predvsem pa se teorija kaosa prepozna po tem, da poudarja pomen radovednosti posameznika $v$ karieri, saj ga bo le radovednost vodila do raziskovanja sveta. Po Schlesingerju in Daleyjevi (2016) je namreč raziskovanje glavna dejavnost kariernega razvoja, zato naj karierni svetovalec svetovanca spodbuja k samoraziskovanju, da bo lažje konstruiral pomen $v$ kaotičnem sistemu. Po Pryorju, Amundsonu in Brightu (2008) je zato treba svetovanca opremiti s strategijami za odločanje in razmišljanje $v$ današnjem tveganem svetu $v$ okviru verjetnosti in možnosti - to pa ga vodi do inovacij in iskanja pomena.

V okviru sledečega pristopa in teorije se kot konstruktivistične ideje prepoznajo predvsem izpostavljanje pomena izkušenj za pot do odkrivanja resnice oz. znanja, naravnanost na individuuma (saj je ta odgovoren za lastno kariero) in njegovo osebno odgovornost pri zrelem, racionalnem kariernem odločanju. Naslednji pristop, ki ga opisujemo, prav tako poudarja dinamičnost in kompleksnost današnje družbe.

\section{Pristopi v kariernem svetovanju v socialnodinamičnem svetu}

Socialnodinamični pristop kariero uvidi kot proces neprestanih sprememb in gibanja. Sestavljata ga dve besedi, ki opisujeta današnjo spreminjajočo se družbo - socialno in dinamično. Gre za pristop, ki posameznike uvidi kot socialna bitja, ki se neprestano spreminjajo (McMahon 2017). Po McMahonovi (2017) pristop v kariernem svetovanju poudarja pomen uporabe refleksije in dialoga, saj se na ta način zagotovi prenos povratne informacije med svetovalcem in svetovancem, po Elkindu (2004) pa je prav dialog ključni poudarek socialnega konstruktivizma. Na ta način se v svetovalnem procesu dogaja skupna konstrukcija, ki je kot mediacijski proces in vodi do neke skupne akcije - to je lahko nova perspektiva, resnica, rešitev, izbira, refleksija, kritično razmišljanje, oblikovanje trdnejših/-e identitet/-e, odnos pa tudi artikuliranje 
življenjskih izkušenj (McMahon 2017). Jezik je namreč po Foxu (2001) eden izmed možnih poti do resnice (znanje se oblikuje v dialogu). Savickas (Lablarios 2013) tudi pravi, da takrat, ko nekaj izrečemo, to postane resnica. Torej izid kariernega svetovanja ne sme biti namestitev posameznika ( $\mathrm{n}$ np. poklic ali vzgojno-izobraževalne institucije), ampak skupno iskanje dosežkov - kaj pa je dosežek, je odvisno od vsakega posameznika (McMahon 2017).

Tako kot teorija kaosa tudi socialnodinamični pristop poudarja kompleksnost današnje spreminjajoče se družbe, vendar pa ta pristop, drugače kot teorija kaosa, posameznika bolj specificira kot socialno bitje. Zatorej bi lahko sklenili, da se kot prva pomembna različica konstruktivizma tu kaže socialni konstruktivizem, ki poudarja formiranje resnice oz. znanja v socialnem kontekstu. Začenja pa se vrednotiti še pomen jezika (dialog) v svetovalnem procesu kot pot do odkrivanja resnice.

$V$ nadaljevanju se najprej posvečamo dvema pristopoma, ki temeljita na (socialnem) kontekstu kariere. Le tako bomo namreč razumeli celovitost novodobne kariere in potrebo po pripovednem pristopu v kariernem svetovanju. Zatem pa se posvečamo še pristopom, ki se bolj poglabljajo v pripovedni pristop v kariernem svetovanju.

\section{Usmerjenost $v$ iskanje ciljev in rešitev na podlagi divergentnih procesov mišljenja}

Sledeči pristop kariernega svetovanja kariero razume kot sestavljeno iz več različnih področij posameznikovega življenja, npr. družinsko, odnosno, poklicno kariero itn. Vse te kariere pa so konstruirane skozi ciljno naravnan proces akcij in projektov (Young in Valach 2004). Pristop temelji na kontekstualnem pogledu na svet, saj kariero razume kot kontekst, $v$ katerem posamezniki živijo. Pristop sam tudi močno poudarja pripovedni pristop kot pomemben del socialnega konstruktivizma $v$ okviru kariere - tako kot Young in Valach (2004) tudi poudarjata, da je bil socialni konstruktivizem glavna ideja za osnovanje sledeče teorije oz. pristopa. Po Youngu idr. (2011) ter McMahonovi (2017) se $v$ okviru svetovalnega procesa namreč svetuje razvoj delovnega pakta med svetovalcem in svetovancem, identifikacijo in naslavljanje akcij, projektov in kariere svetovanca. Posebno pozornost pa svetovalec namenja še svetovančevim čustvom. Na koncu pa je pomembno, da se akcije in projekti, ki se v svetovalnem procesu naslavljajo, dejansko realizirajo v posameznikovem življenju (tj. ciljna naravnanost) (Young idr. 2011; McMahon 2017). Obenem pa nas Young in Valach (2004) spomnita, da te akcije pravzaprav napajajo čustva, torej nas skozi pristop opozorita, da čustva igrajo pomembno vlogo pri učenju. To bi lahko povezali s konstruktivističnimi idejami 
na ta način, da se odgovornost posameznika za samoaktualizacijo poudarja kot pomembna.

\section{Sistemsko karierno konstruiranje}

To je ena izmed sistemskih teorij, v okviru kariere je sistemski teoretični ovir (angl. System Theory Framework, STF), ki kariero razume kot karierni razvoj, na katerega vplivajo vsebinski in procesni dejavniki (McMahon in Patton 2004; McMahon in Watson 2008). Vsebinski vplivi vključujejo lastnosti, ki so notranje posamezniku (npr. spolna orientacija, interesi, starost, sposobnosti, osebnost ...), hkrati pa se teorija zaveda, da posamezniki ne živijo v izolaciji, ampak so del širšega vsebinskega sistema, ki obsega še družbeni (npr. družina, vzgojno-izobraževalne institucije, mediji, vrstniki ...) in okoljski sistem (npr. politika, globalizacija ...). Procesni vplivi pa so tisti, ki pravzaprav narekujejo dinamiko kariernega razvoja - to so naključja in večsmerni, skozi čas spreminjajoči se procesi (McMahon in Watson 2008). To nas spomni, da posameznikov karierni razvoj ne more biti vedno načrtovan, logičen in ni vedno mogoče točno napovedati, kakšen bo v prihodnosti, saj nanj vplivajo priložnosti in naključja. Torej kontekstualno paradigmo pristop prevzema drugače kot omenjeni socialnodinamičen pristop.

Karierno svetovanje po STF prav tako temelji na pripovednem pristopu, saj spodbuja samorefleksijo posameznika z uporabo pripomočka, s pomočjo katerega lahko posameznik vodi refleksijo ${ }^{2}$ svojega kariernega razvoja in dejavnikov, ki so vplivali in vplivajo na njegov karierni razvoj skozi vse tri vsebinske sisteme. To je pripomoček za identifikacijo kariernih vplivov (angl. My System of Career Influences, MSCl) (McMahon in Watson 2008), ki lahko obogati karierno svetovanje. $\mathrm{MSCl}$ refleksijo svetovanca vodi $z$ različnimi vprašanji, ki spodbujajo samozavedanje in karierno zavedanje za lažje karierno odločanje (McMahon in Patton 2004). Tako bi lahko dejali, da se z MSCl pravzaprav spodbuja metakognicija posameznika. Metakognicija pa je posebej omenjena $v$ karierni teoriji spoznavno-informacijskega procesa kariernega odločanja po Sampsonu idr. (2003), ki jo prav tako uvrščamo v konstruktivistične karierne teorije; v okviru navedene karierne teorije se namreč zgolj s pomočjo metakognicije posameznik lahko zrelo karierno odloča.

Vseskozi se nam po vseh doslej omenjenih pristopih izpostavlja pomen integracije socialnega konteksta in psiholoških dejavnikov (Young in Valach 2004) za osmišljanje lastne kariere. To pa naj bi se doseglo s pripovednim

\footnotetext{
${ }^{2}$ McMahon in Patton (2004) svetujeta, naj MSCl poteka v interakciji, saj konstruktivizem poudarja, da se tako konstruira pomen oz. zgodbe dobijo pomen.
} 
pristopom, v katerem se vrednoti pomen jezika, skozi katerega se lahko konstruira resnica. Zato se zdi edino primerno, da se poglobimo $v$ pristope, $\mathrm{ki}$ natančneje opisujejo sam pripovedni pristop v kariernem svetovanju.

\section{Karierne konstrukcije preko pripovedovanja zgodb}

Svetovalci, ki pri kariernem svetovanju uporabljajo pripovedni oz. narativni pristop, ${ }^{3}$ spodbujajo svetovance, da pripovedujejo zgodbe o svojem življenju, ter jim pomagajo, da te zgodbe osmislijo in prepoznajo ključne teme v njih (Mcllveen in Patton 2007). Svetovalec in svetovanec sta angažirana sodelavca $v$ reflektivnem, skupnem, paralelnem procesu odkrivanja ene ali več življenjskih tem, zgodb oz. resnic in sokonstruirata bodoče epizode (prehode) svetovanca (Savickas 2012). Dobra zgodba o sebi namreč svetovanca spodbuja h kariernim prehodom tako, da obdrži svojo samopodobo, vendar pa jo hkrati še bolj utrdi, da postane vitalnejša in namernejša oz. ciljno naravnana. Ko se zgodba sokonstruira v tem odnosu, postane prenovljena identiteta svetovanca, ki omogoča, da je ciljno naravnan pri soočanju z negotovostjo prehoda - torej da se namere spremenijo v smiselno vedenje in delovanje (Savickas 2012) Oz. akcije (Krieshok, Black in McKay 2009). Akcija namreč spodbuja nadaljnje samostojno ustvarjanje, oblikovanje identitete in kariere.

Svetovanec si med svetovalnim procesom izbere neko zgodbo, ki deluje kot vodilna metafora in postane orodje svetovanja oz. življenjska zgodba, v kateri mora prevzemati glavno vlogo, saj se odvija na njegovi življenjski poti (Savickas 2011; Patton in McMahon 2018). Ta življenjska pot je tudi osnova za pristop svetovanja z zgodbami, za odkrivanje in gradnjo nove zgodbe svetovanca, $v$ kateri se bo znašel na prehodu na lastni karierni poti in zaradi katere je pravzaprav prišel po nasvet (Savickas 2011).

Med svetovalnim procesom je prostor še za to, da posameznik odkriva svoje preference, ${ }^{4}$ ki naj bi mu pomagale pri odločanju za prehod (Brott 2017). Pomaga si lahko s kvantitativnimi tehnikami. Vendar pa je izid testa zgolj objektivna ocena, ki v tem svetovanju nima velikega pomena, kakor tudi ne služi kot orodje za potrditev ustreznosti odločitve, npr. poklicne ustreznosti (Brott 2007) - izid je zgolj ena izmed mnogih resnic. Prevladujejo pa naj subjektivna dejstva, saj predstavljajo veliko bogatejšo in natančnejšo metodo

\footnotetext{
${ }^{3} \mathrm{~V}$ zadnjem desetletju se je zgodil očiten premik v fokusu kariernega svetovanja, saj so zgodbe postale ključno orodje $v$ svetovalnem procesu, a niso nekaj povsem novega. Ta pristop najdemo že pri Kellyju (»George Kelly« 1995) kot obliko osebnega konstruiranja.

${ }^{4}$ Tu se poraja vprašanje, ali naj se na tem mestu še uporabljajo klasična ocenjevalna orodja za ugotavljanje lastnosti osebe (npr. Hollandov test). Savickas (2012) meni, da je to smiselno, a Brottova (2012) poudarja, da je bistveno samoocenjevanje svetovanca.
} 
razumevanja, kako ljudje dejansko sodelujejo pri načrtovanju kariere (Spangar 2004). Grant in Johnson (2006) trdita, da je vse, kar povedo svetovanci, subjektivno, tudi njihove odločitve in uspešen razvoj kariere, kar pomeni, da tega vidika ne smemo zanemariti. Tak pristop ponuja tudi povsem nov način opredelitve vloge kariernega svetovalca, ki ni več vzvišen, $z$ visoko strokovno avtoriteto in v vlogi presojanja, ampak postane sodelavec svetovanca, spodbujevalec, subjektivna ocena ustreznosti karierne odločitve pa postane svetovančeva odgovornost (Savickas 2011).

McLeod (1996) tako svetuje nekaj skupnih konceptov, ki jih je treba upoštevati v pristopu s pripovedmi - življenjske teme ( $k$ so delo $z$ življenjsko zgodbo), razvijanje pripovedi, primerjava različnih zgodb, dekonstrukcija pomena, svetovalec kot občinstvo, sokonstruktor in urednik ter pisanje kot terapevtsko dejanje. Vsi ti načini pripovednega pristopa imajo za cilj konstruiranje bodočega kariernega razvoja, predvsem pa kreiranje naslednjega prehoda (McLeod 1996). Da bi bolje razumeli zgodbe v vlogi nasvetov za sprejemanje odločitev na prehodih, si moramo pogledati še, kako se konstruirajo nove zgodbe in epizode.

\section{Dekonstruiranje pretekle poti in konstruiranje nove}

Pripovedni oz. narativni pristopi se ne osredotočajo zgolj na pojem poklicne kariere, pač pa širše - na celo življenje in osmišljanje življenja, tako kot to lahko prepoznamo v pristopu, usmerjenem v iskanje ciljev/rešitev, ki po Valachu in Youngu (2004) v sedanjem načinu hitrega življenja postaja eno izmed pomembnih človekovih epistemoloških vprašanj. Vendar pa je Savickas (v Brown 2002) tisti, ki je postavil ključne podlage za teorijo gradnje kariere, ${ }^{5}$ ki jo slikovito poimenuje kot oblikovanje življenja (angl. life design) in pomeni nekakšen okvir za kreiranje kariernega razvoja v 21. stoletju, v katerem so sodobni delavci soočeni z negotovostjo in s hitrimi spremembami. $V$ tem kontekstu naj bi posamezniki svojo kariero gradili na življenjskih temah (okolju) in samopodobi, ki jih usklajujejo v zamišljeno idealno življenjsko zasnovo. Posamezniki svojo kariero postavljajo na pomenu zanje, ne pa na vnaprej določeni karierni vlogi ali položaju.

Pristop vrednoti pomen avtobiografske zgodbe. Na ta način vsak posameznik, ki gradi svojo kariero, ustvari nekakšen biografski most, ki ga prenese v

\footnotetext{
${ }^{5}$ Savickasov pristop ima veliko skupnega $z$ drugimi kontekstualističnimi/konstruktivističnimi pristopi, ki smo jih že omenjali. Vsi ti imajo isti cilj, in sicer, po Savickasu (2011), spodbuditi pomembne dejavnosti za nadaljnje samostojno ustvarjanje, oblikovanje identitete in konstruiranje kariere.
} 
prihodnost (Savickas 2012). Konstruiranje bodočih zgodb temelji na obdelavi lastne biografije (Heinz 2002), za kar posamezniki poiščejo svetovalca, kjer se pričnejo intervencije življenjskega načrtovanja tako, da opišejo pomemben dogodek, ki jih dislocira od trenutne epizode $v$ njihovi zgodbi, in cilje novega scenarija, ki ga želijo zgraditi s svetovalcem. Preko malih zgodb ${ }^{6}$ prikažejo, kako so zgradili svojo identiteto in kariero. Te zgodbe so $\mathrm{v}$ bistvu konstrukcijska orodja za gradnjo identitet/-e in karier/-e v zapletenih družbenih interakcijah sedanjega časa. Vendar pa ima življenje posameznika tudi "problematične zgodbe«, ki ga bremenijo in zavirajo pri vodenju kariere oz. izgrajevanju življenja. Zato nastane potreba, da bi se zgodbe svetovanca dekonstruirale, da bi razkrile samoomejujoče ideje, omejene vloge in kulturne ovire (Savickas 2012). Savickas (2012) pravi, da moramo biti v današnji karieri optimistični, prilagodljivi in temeljiti na znanju. ${ }^{7}$ Tu gre tudi za nekakšno refleksijo, ki zahteva, da premislimo o sebi z različnih zornih kotov, da bi prišli do dejanskih spoznanj o svoji realnosti (Guichard 2016). Cilj je dostop do različnih pomenov in novega znanja na osnovi divergentnega razmišljanja, ki odpira možnosti in znova zažene zastale pobude. Vloga svetovalca pa je, da najde ustrezne načine za spodbuditev procesa $v$ smislu, da pomaga sokonstruirati pripovedi (Hartung 2013). Vse to poteka kot dinamičen interrelacijski proces, ki ga je mogoče opredeliti kot sokonstruiranje, dekonstruiranje in konstruiranje. Brottova (2012) pa temu doda še rekonstruiranje.

$V$ tem podpoglavju pravzaprav govorimo o pripovedni analizi, v prejšnjem podpoglavju pa smo se nanašali zgolj na pripoved. Analiza pripovedi je pravzaprav neke vrste rekonstrukcija dogodkov, saj posameznik v ta proces vnaša drugačne ugotovitve $z$ različnih gledišč, v katera ga spodbuja svetovalec. Pri tem se kot zelo pomemben izpostavlja socialni kontekst zgodb (Guichard 2016). Pri delu z malimi pripovedmi svetovalec aktivno zbira in povezuje te zgodbe kot delce v enotno, mozaično podobo, da oblikuje celosten občutek individualnosti (Savickas 2011). Potemtakem lahko razumemo, da integracija majhnih zgodb o sebi v družbenih situacijah tvori veliko zgodbo ali makropripoved, to pa je pripoved o identiteti. Ta pripoved, ki igra vlogo spoznavanja lastne identitete, pojasnjuje preteklost svetovanca, ga usmerja v sedanjost in vodi $v$ prihodnost. Potem pa je treba te male zgodbe aktivirati in povezati (Ricoeur 1984). Aktivirati pomeni umestiti v kontekst velike zgodbe o tem, zakaj se je to zgodilo. Umestitev zaporedja epizod v večjo zgodbo dodaja

\footnotetext{
${ }^{6}$ Vsako izobraževanje ali opravljanje poklica lahko v »romanu« njihove kariere razumemo kot kratko zgodbo.

${ }^{7}$ To kaže, da Savickas nove koncepte povezuje s teorijami kariernega razvoja na osnovi socialnega učenja.
} 
pojasnjevalne povezave in vzročno skladnost izkušnjam, ki so sicer še vedno naključne. Torej pri načrtovanju življenja rekonstrukcija pomeni konfiguriranje in integracijo agenta, ciljev, sredstev in interakcij, da se tvori enotna in smiselna pripoved o identiteti (ali življenjski portret ali mozaik).

\section{Samopodoba, dialog s seboj in karierno samoraziskovanje}

Poudarili smo, da je osrednji način konstruktivističnega svetovanja pripovedna tehnika, ki ima različno razlagalno vsebino in pomen v procesu svetovanja. Mcllveen (2017) jo uporablja predvsem v kontekstu »dialoškega jaza«, kar pomeni, da je zanj bistveno, kaj se dogaja v posamezniku, ko pripoveduje svojo/-e zgodbo/-e v svetovalnem procesu gradnje kariere.

Ljudje kot živa bitja imamo veliko posebnih sposobnosti, ki nas ločujejo od drugih bitij. Imamo zmožnost besedne konverzacije, poslušanja, parafraziranja, simpatije in sočutja. Pri tej človeški sposobnosti je resnično izjemno to, da tok teh misli (dialog) teče $v$ naši zavesti, četudi ni navzočega sogovornika (Mcllveen 2017) (kot samousmerjevalni govor). Ta tok v osnovi pomeni, da govorimo o dialoškem jazu. Ves čas namreč v naših glavah slišimo te pogovore, kot da bi bile poleg individualnega jaza prisotne še množice nezavednih glasov. Že eno samo vprašanje, ki si ga postavimo in nanj odgovarjamo, nas popelje $v$ več rešitev, v ozadju katerih se pletejo tudi druga povezana vprašanja, kot je to, zakaj se to postavlja, kako bi to vprašanje postavila neka druga oseba itn. To pomeni, da ima človek veliko družbenih jazov (Hermans 2003). To nenehno »brbljanje« človek slikovito sliši, kako se dogaja v njegovi glavi. Kognitivni viri in pozornosti pa mu omogočajo, da se osredotoči na poseben dialog med omejenim številom jaz-položajev (Lysaker in Lysaker 2002).

$V$ tem trenutku ocenjujemo, da »dialoški jaz« najbolj prispeva $k$ teoriji in praksam pripovednega kariernega svetovanja, saj ponuja teorijo za razumevanje procesa psihološkega ustvarjanja zgodb (Hermans 2003). Gre torej za pristop, kjer kontekstualistična perspektiva decentrira lastnosti samega sebe (Mcllveen 2017) v medsebojni sistemski prepletenosti (Patton in McMahon 2006; 2014). Posameznik je vključen v mnogo interakcijskih sistemov, saj je svojstven biološki in psihološki sistem z množico drugih podsistemov, ti pa se povezujejo z zunanjim svetom, polnim zapletenih sistemov - in vse to posameznik neprestano odslikava v svoji zavesti. Torej lahko razumemo, da je tudi posameznik sam kaotični sistem.

\section{Zaključek}

Namen prispevka je predstaviti določene pristope, ki jih označujemo za novodobne. To so pristopi v okviru kontekstualizma/konstruktivizma. Zato smo preučili novosti, ki jih prinašajo v karierno svetovanje. Glede na navedeno 
bi lahko rekli, da pripoved postaja osrednji instrument $v$ konstruktivističnem pristopu kariernega svetovanja, ki izhaja iz kontekstualizma. Ta pa očitno še zdaleč ni jasno oblikovan in zaokrožen sklop metod in tehnik. Lahko bi rekli, da je produkt divergentnega razmišljanja, ki ni osredotočeno na iskanje ene najboljše rešitve, pač pa na paleto možnih rešitev v okviru zaporedja konstruiranja zgodb življenja. Pripovedovanje zgodb je $v$ bistvu socialnodinamični proces.

Spangar (2004) poudarja, da ta metoda ni tradicionalno svetovanje $v$ smislu, da bi najprej ustvarili teoretični okvir, nato pa razvili posebne metode svetovanja in jih uporabili $v$ svetovalni praksi. To je pravzaprav dialog $s$ teoretizacijo in z izkušnjami resnične svetovalne prakse. Temelji na filozofskih idejah pomena človekovega obstoja, v katerem se ljudje borijo za ustvarjanje smisla v svojem življenju, postopek svetovanja pa je proces, kako svetovancem pomagati, da v življenju osmislijo svoje življenjske odločitve, vključno s svojimi poklicnimi odločitvami (Spangar 2004). Savickas (2012) npr. pravi, da njegova paradigma življenjskega oblikovanja ne nadomešča standardnega poklicnega usmerjanja in poklicnega izobraževanja, temveč ju dopolnjuje. $\checkmark$ bistvu nastaja nekakšna skupna konstruktivistična paradigma za karierno svetovanje, ki vključuje vrsto modelov in konceptov $z$ istim jedrnim konceptom, med katere lahko prištevamo vse omenjene pristope kariernega svetovanja. Vsak od teh pristopov uporablja zgodbe, jezik, (meta)kognicijo, refleksijo in čustva.

Po Savickasu (2011) sčasoma vsak posameznik, ki se sooča s prehodi, s pomočjo zgodb ustvari biografski most, ki izraža njegove osebne resnice in ga prenese v prihodnost, na njegovo življenjsko pot preko kolaborativnega odnosa s svetovalcem, pomembno pa je, da svetovanec ostaja aktiven in ciljno naravnan. Zato moramo priznati, da konstruktivistični pristopi h kariernemu svetovanju prinašajo mnogo koristi, predvsem za vodenje kariere v družbi tveganja, čeprav Mcllveen (2007) priznava, da v okviru pripovedne tehnike ne moremo govoriti o neki standardni obliki kariernega svetovanja, saj ji manjkajo konkretna orodja in praktična uporaba.

Tu pa se lahko še vprašamo, kako graditi naprej prakso in teorijo. Zaznati je pobude o skupnem konceptualnem nastopu pri razvoju modela in metod za oblikovanje življenja (angl. life design), ki se zaenkrat nekako zdi najkompatibilnejši pristop in paradigma za sedanje razmere dela (po Savickasu 2012).Vse bolj se izraža tudi tendenca po medkulturnem povezovanju in mednacionalnem sodelovanju, kar se odraža tudi v nastanku mednarodne raziskovalne skupine Life Design, ki povezuje strokovnjake iz heterogenih okolij (Avstralije, Kitajske, Anglije, Francije, Japonske, Izraela, Južne Afrike in drugih), s či- 
mer bi se pridobilo internacionalno veljavo in splošno uporabljivost. S tem si lahko odgovorimo na vprašanje, kam vodi pot nadaljnjega teoretskega raziskovanja in prakse na področju kariere: težko je napovedovati, vendar se bolj kaže smer v sintezo teorij in praks.

Po pregledu literature in drugih virov, ki smo jih preučili, ugotavljamo, da že obstaja zbirka tehnik in orodij, specifičnih za karierno svetovanje in učenje v kontekstu kreiranja življenja. Vključuje tradicionalna orodja poklicne orientacije kakor tudi nova orodja, ki jih je oblikoval socialnokonstruktivistični pristop kariernega vodenja (npr. genogrami, zgodnji spomini in dopolnitve stavkov, ki se uporabljajo z namenom, da spodbujajo in podrobno opisujejo karierne pripovedi ...). Pri tem lahko uporabljamo spletne portale in spletna orodja, ki omogočajo neposredno uporabo najširšemu krogu interesentov. Digitalizacija je odprla neverjetne možnosti uporabe vseh teh pripomočkov in metod, kar omogoča avtonomijo pri vodenju kariere oz. za uspešno načrtovanje prehodov $v$ življenju. $S$ tem posameznik postane pravi menedžer lastne kariere, ki jo mora vseskozi osmišljati.

\section{Literatura}

Ažman, T., M. Lovšin, A. Kohont in D. Zaviršek, ur. 2014. Moja kariera: informacije za otroke, učence, dijake, študente, mlade in odrasle, starše in strokovne delavce. Ljubljana: Center RS za poklicno izobraževanje.

Biswas, R. H., M. M. Hasan in K. S. Bala. 2018. „Chaos Theory and Its Applications in Our Real Life." Barishal University Journal Part 15 (1-2): 123-140.

Bright, J. 2013. »Chaos Theory of Careers Explained - Interview with Dr. Jim Bright at Vanderbilt University.« YouTube. 4. februar. 10:43. https://www .youtube.com/watch?v=BL2wTkgBEyk.

Brott, P. E. 2012. »A Career Story Approach to Management, Business, and Financial Occupations. " Journal of Employment and Counselling 49 (4): 146-191.

_.2017. »The Storied Approach. «V Career Counselling:Constructivist Approaches, ur. M. McMahon, 93-103. Oxon: Routledge.

Brown, D. 2002. Career Choice and Development. 4. izd. San Francisco, CA: Jossey-Bass.

Collin, A. 1997. »Career in Context.« British Journal of Guidance and Counselling 25 (4): 435-446.

Collin, A., in R. A. Young. 1986. »New Directions for Theories of Career.« Human Relations 39 (9): 837-853.

Drobnič, J. 2018. Kariera in osebe s posebnimi potrebami. Koper: Založba Univerze na Primorskem.

- 2020. »Poklicne odločitve in vodenje kariere v kontekstu avtonomnosti in samoodločanja." Šolsko polje: revija za teorijo in raziskave vzgoje in izobraževanja 37 (3-4): 167-184. 
Elkind, D. 2004. »The Problem with Constructivism. «The Educational Forum 68 (4): 306-312.

Fox, R. 2001. »Constructivism Examined.« Oxford Review of Education 27 (1): 2335.

»George Kelly.« 1995. Personal Construct Psychology. http://ksi.cpsc.ucalgary .ca/PCP/Kelly.html.

Ginzberg, E. 1984. „Career Development.« V Career Choice and Development, ur. D. Brown in L. Brooks, 169-191. San Francisco, CA: Jossey-Bass.

Gottfredson, L. S. 2002. „Gottfredson's Theory of Circumscription, Compromise and Self-Creation. «V Career Choice and Development, ur. D. Brown, 85-148. San Francisco, CA: Jossey-Bass.

Grant, M. E., in A. J. Johnston. 2006. „Career Narratives." V Career Counseling: Constructivist Approach, ur. M. McMahon in W. Patton, 110-122. Abington: Routledge.

Guichard, J. 2016. »Reflexivity in Life Design Interventions: Comments on Life and Career Design Dialogues." Journal of Vocational Behavior 97:78-83.

Hartung, P. J. 2013. „The Life-Span, Life-Space Theory of Careers. « V Career Development and Counseling: Putting Theory and Research to Work, ur. S. D. Brown in R. W. Lent, 83-113. Hoboken, NJ: Wiley.

Heinz, R. W. 2002. »Transition Discontinuities and the Biographical Shaping of Early Work Careers. « Journal of Vocational Behavior 60 (2): 220-240.

Hermans, H. J. M. 2003. »The Construction and Reconstruction of a Dialogical Self.« Journal of Constructivist Psychology 16 (2): 89-130.

Klemenčič, E. 2012. Globalizacija edukacije. Ljubljana: Demat.

Knol, M. 2011. »Constructivism and Post-Constructivism: The Methodological Implications of Employing a Post-Constructivist Research Approach."Poskusno predavanje, 25. marec. https://munin.uit.no/bitstream/handle/ 10037/4106/article.pdf?sequence $=4$.

Kravos, K. 2019. „Career Management of Special People Needs in the Labour Market.«Economics. Ecology. Socium 3 (3): 11-20.

Krieshok, S. T., D. M. Black in R. A. McKay. 2009. "Career Decision Making: The Limits of Rationality and the Abundance of Non-Conscious Processes." Journal of Vocational Behavior 75 (3): 275-290.

Lablarios. 2013. »M. Savickas's keynote_2013 International conference_Larios.« YouTube. 26. avgust. 40:47. https://www.youtube.com/watch?v=uqz -5ny8T-s\&ab_channel=LABLARIOS.

Lysaker, P. H., in J. T. Lysaker. 2002. »Narrative Structure in Psychosis: Schizophrenia and Disruptions in the Dialogical Self.« Theory \& Psychology 12 (2): 207-220.

Mcllveen, P. 2007. „Counsellors' Personal Experience and Appraisal of My Career Chapter.«Australian Journal of Career Development 16 (2): 12-19.

—. 2017. »Dialogical Self: Co-Investigator in Career Self-Research in Career 
Counselling: Constructivist Approaches. «V Career Counselling: Constructivist approaches, ur. M. McMahon, 153-163. Oxon: Routledge.

Mcllveen, P., in W. Patton. 2007. »Dialogical Self: Author and Narrator of Career Life Themes. International Journal for Educational and Vocational Guidance 7 (2): 67-80.

McLeod, J. 1996. »The Emerging Narrative Approach to Counselling and Psychotherapy."British Journal of Guidance and Counselling 24 (2): 173-184.

McMahon, M., ur. 2017. Career Counselling: Constructivist approaches. Oxon in New York: Routledge.

McMahon, M., in W. Patton. 2004. "Creating Career Stories through Reflection: An Application of the Systems Theory Framework of Career Development."Australian Journal of Career Development 1 (3): 13-17.

McMahon, M., in M. Watson. 2008. "Systemic Influences on Career Development: Assisting Clients to Tell Their Career Stories." The Career Development Quarterly 56 (3): 280-288.

— ur. 2015. Career Assessment: Qualitative Approaches. Rotterdam: Sense.

Niklanović, S. 1997. Prispevki o poklicnem svetovanju. Ljubljana: Izida.

Patton, W., in M. McMahon. 2006. „Constructivism: What Does It Mean for Career Counselling?« V Career Counselling: Constructivist Approaches, ur. M. McMahon, 8-30. Oxon: Routledge.

-2014. Career Development and System Theory: Connecting Theory to Practice. Rotterdam: Sense.

—. 2018. "Systemic Thinking in Career Development Theory: Contributions of the Systems Theory Framework. « British Journal of Guidance \& Counselling 46 (2): 229-240.

Pepper, S. C. 1942. World Hypotheses: A Study in Evidence. Berkeley, CA: University of California Press

Pryor, R. G. L., E. N. Amundson in H. E. J. Bright. 2008. »Probabilities and Possibilities." The Career Development Quarterly 56 (4): 309-318.

Reid, H. 2017. »Usefulness and Truthfulness: Reviewing the Limitations and Promoting the Benefits of Constructivist Approaches for Career Counselling." V Career Counselling: Constructivist Approaches, ur. M. McMahon, 29-39. London: Routledge.

Richardson, V. 2003. »Constructivist Pedagogy. "Teachers College Record 105 (9): 1623-1640.

Ricoeur, P. 1984. "The Model of the Text: Meaningful Action Considered As a Text." Fifty Years of Social Research: Continental and Anglo-American Perspectives 51 (1-2): 185-218.

Sampson, Jr., P. J., W. G. Peterson, C. R. Reardon in G. J. Lenz. 2003. »Key Elements of the CIP Approach Designing Career Services.«https://career.fsu.edu/ sites/g/files/imported/storage/original/application/ ece94c7d70edfe43457c1f616e189324.pdf. 
Savickas, M. L. 1993. »Career Counselling in the Postmodern Era. Journal of Cognitive Psychotherapy: An International Quarterly 7:205-215.

- 2011. „Constructing Careers: Actor, Agent, and Author.« Journal of Employment Counseling 48 (4): 179-181.

- 2012. "Life Design: A Paradigm for Career Intervention in the 21st Century." Journal of Counseling \& Development 90 (1): 13-19.

Schlesinger, J., in L. P. Daley. 2016. »Applying the Chaos Theory of Careers as a Framework for College Career Centers. "Journal of Employment Counseling 53 (2): 86-96.

Spangar, T. 2004. „Using Metaphors and Ceremonies in Career Counseling.« V Counselling as a Profession and Subject of Research: Counselling Methods; Counselling Handbook, Part 3, ur. J. Onnismaa, H. Pasanen in T. Spangar, 198-207. Jyväskylä: PS-Kustannus.

Super, D. E. 1990. »A Life-Span, Life-Space Approach to Career Development.« V Career Choice and Development, ur. D. Brown in L. Brooks, 197-261. San Francisco, CA: Jossey-Bass.

Valach, L., in R. A. Young. 2004. "Some Cornerstones in the Development of a Contextual Action Theory of Career and Counselling.« International Journal for Education and Vocational Guidance 4 (1): 61-81.

Young, R. A., in L. Valach. 2004. »The Construction of Career through GoalDirected Action. "Journal of Vocational Behavior 64 (3): 499-514.

Young, R. A., S. K. Marshall, K., Foulkes, C. Haber, C. S. M. Lee, C. Penner in H. Rostram. 2011. "Counseling for the Transition to Adulthood as Joint, GoalDirected Action.« Journal of Vocational Behavior 79 (2): 325-333.

\section{Career Counselling for Transitions in the Context of Constructivism}

New career counseling methods based on constructivism are increasing because of rapid changes in today's society; therefore, individuals need to become autonomous and responsible for their careers. Our paper presents these new career counseling methods, based on contextualism/constructivism and the approaches valued in contemporary career counseling. We acknowledge the narrative approach as the main constructivism-based approach to career counseling, which is recently becoming important in vocational psychology and career counseling practice. Narration in career counseling serves as the construction of meaning about ourselves and our careers through stories, language and in current career counseling values the understanding of a person's feelings, (meta) cognition, learning, goal-directed behavior, flexibility, learned optimism, and personal responsibility for career guidance. Stories aid in the career decision-making process and are a bridge for transitions in our career development.

Keywords: constructivism, contextualism, career counseling, transitions, career guidance 